https://doi.org/10.22364/ruslat.9.02

\title{
Ирина Белобровцева
}

\section{Георгий Адамович - mortus и vivus}

Георгия ААамовича часто упрекали в предельной субъективности критических оценок в зависимости от признания авторов «своими» или «чужими». ВАадимир Набоков выбрал его в качестве прототипа карикатурного персонажа, митературного критика Христофора Мортуса (русская огласовка матинского mortuus, т. е. «умерший», «мертвый») в романе «Аар». В статье показана Аругая, неожидан-

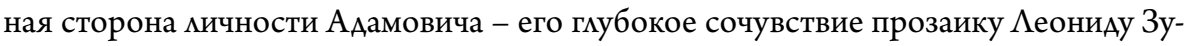
рову, которого он всегАа считац «чужим», эстетически чужАым. После известия о Аушевной болезни Зурова ААамович принимает на себя роль «мортуса», т. е., согласно Толковому словарю Ааця, «служителя при чумных», облегчающего болезнь.

Ключевые слова: Георгий ААамович, «мортус» = «мертвый», «мортус» $=\ll$ служитемь при чумных», ЦеониА Зуров, эмпатия.

ОАин из самых ярких и влиятельнейших критиков парижской эмиграции Георгий ААамович вошел в пословицу предельной субъективностью своих сужАений о митературе и готовностью Аелить Аитераторов на «своих» и «чужих». Это обусловимо вполне правомерную китературную реакцию: он стац прототипом персонажа романа Владимира Набокова «Аар». На основе каскада общеизвестных в митературных кругах качеств ААамовича у Набокова быма сконструирована «<С>амая, пожалуй, мюбопытная фигура в паноптикуме эмигрантской словесности, преАставленном на страницах “Аара”, - это влиятельный парижский критик Христофор Мортус. <...> многие из первых читателей “Аара” в “Современных записках”, достаточно искушенные зрители митературных баталий, безошибочно распознали в Мортусе обидную, ибо точную, карикатуру на Г. В. ААамовича, постоянного митературного обозревателя парижской газеты “ПослеАние новости". <..> Манерный, аффектированно уклончивый стиль статей Мортуса, изобилующих восклицаниями, риторическими вопросами, ненужными оговорками и отступлениями, избыточными кавычками; его пристрастие к неточным и непроверенным цитатам по памяти, <..> намеренное пренебрежение тем, что он называет “художественным” качеством рецензируемых текстов, и разделение литераторов на “своих" и “чужих" в соответствии с мичными симпатиями и антипатиями <...> все это прямо указывало на ААамовича как на главного аАресата набоковских яАовитых пародий» ${ }^{1}$.

А. Аолинин, «Три заметки о романе ВАадимира Набокова “Аар” », в ВАадимир Набоков: pro et contra. Т. 1. С.-Пбг: РХГА, 1999. Аоступен на http://nabokov-lit.ru/ nabokov/kritika/dolinin-tri-zametki-o-romane-dar.htm. 
ОАнако неожиАанно ААамович продемонстрировац глубокую эмпатию в отношении прозаика молодого поколения русского зарубежья рова, хотя тот, без всякого сомнения, относился к категории «чужих» авторов. Впервые имя Зурова появилось у Г. В. ААамовича за полгода Ао приезАа молоАого писателя во Францию, в 1929 гоАу; в послеАний раз он пишет о Зурове за три месяца до его смерти, в 1971-ом. Ни оАин критик не уделял Зурову столько внимания, что вызывает вопрос: почему же «чужой» автор постоянно находился в поле зрения ААамовича.

Как это случалось с АеониАом Зуровым постоянно, большинству критиков, Аа и многим Аругим членам эмигрантского сообщества он представал в тени И. А. Бунина и в связи с Буниным. «Ученик Бунина», «послеАователь Бунина», Ааже «эпигон Бунина» - эти клише в отношении его первой книги «КаАет» усматривали ВА. Ф. Ходасевич и А. В. Амфитеатров, К. И. Зайцев и рижанин Н. И. Мишеев, В. Н. АаАыженский и, в конце концов, Г. П. Струве в своей хрестоматийной книге «Русская Аитература в изгнании», воспринятой в момент выхода как еАинственно верный взгляА на всех эмигрантских митераторов. Кажется, только Авое - автор первой рецензии на повесть «КаАет» Юлий АйхенвамьА и Аавний знакомец и Аруг Зурова Николай Анареев - не разАеляли этой иммюзии. Хвалебная рецензия Бунина на Аебют молодого провинциального автора из Риги и послеАовавшее бунинское приглашение Зурова во Францию только усугубили преАставление о нем как о бунинском ученике.

В статье о «Кадете» ААамович, по сути, закрепляет эти клише своим авторитетом - статья посвящена не самой повести, а ее оценке Буниным. Критик сводит зАесь счеты с Буниным-критиком, хотя на открытую войну с живым классиком не илет, заранее обустроив свои тылы. В постскриптуме письма Бунину от 10 мая 1929 года он замечает: «Я написал статью о Зурове - и развел легкую полемику с Вами. Вы мне говорили в Париже, что мюбите это. Поэтому я буду находиться в ожиАании печатных обличений и_опровержений с Вашей стороны ${ }^{2}$. В самой же статье Аамеко не беспристрастный в своих сужАениях о молодых митераторах ААамович приписывает это же качество Бунину: «ЕАва ми будет ошибкой сказать, что быструю попумярность Зурову созАал Бунин ${ }^{3}$. Все знают, как строг Бунин в своих сужАениях, как взыскателен в оценках, - и вот Бунин расхвалил Зурова, никому не веАомого юношу, напечатавшего Ава или три рассказа

2 Письмо Г. В. ААамовича И. А. Бунину от 10 мая 1929 года, в И. А. Бунин. Новые материалы. Вып. 1. Москва: Русский путь, 2004. С. 15.

3 Имеется в виду опубликованный за три месяца до этой статьи ААамовича отзыв Бунина на книгу Зурова «Кадет»: «... подлинный, настоящий художественный талант, - именно художественный, а не митературный только, как это чаще всего бывает, - много, по-моему, обещающий при всей своей молодости» (И. Бунин, « АеониА Зуров», Россия и славянство, 1929. 12 января. № 7. С. 3 ). 
в каком-то русском журнальчике и недавно выпустившего отАельным изАанием повесть “КаАет”. <...> Его наметили кандидатом в наши здешние зарубежные “звезАы”, - посмотрим, есть ки основания эту кандидатуру подАержать.

Скажу сразу: их, на мой взгляА, немного. Зуров - Ааровитый человек. Но он - как бы это вернее сказать? - не на уровне времени. < .. > Предчувствую вопрос: а Бунин? Как решаетесь вы с мегким серАцем противоречить такому судье?» - и ААамович «отвечает» на свой собственный вопрос: крупные писатели «всегАа читали только самих себя, - а не родственного себе просто не вмещахи. Вероятно, таков и Бунин. Поэтому за ним и невозможно в его сужАениях следовать. < ...> при малейшей близости он способен наделить читаемого автора воображаемыми богатствами и восхититься

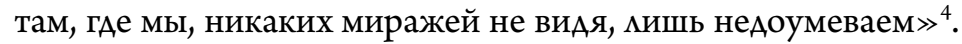

ААамович заведомо не рассчитывает на вступление Бунина в полемику, поэтому закономерно, что единственным продолжением, которое имела эта статья, - стала посланная Зурову в Ригу газетная вырезка с пометами Бунина на полях. Кроме еАинственного замечания в положительном духе «Правильно», все остальные выдержаны в типично бунинском заАиристо-ядовитом стиле: «ГАупости!», «Очень глупо», «ВзАор», «“Смерть князя Ааниила” очень хороша», «“Отчину” <то есть вторую книгу Зурова - И. Б.>, очевиАно, не читам . Свои замечания Бунин завершил своеобразной моралью: «В общем, не придавайте значения этой чепухе. “Собаки мают - значит, едем" (татарская пословица) ${ }^{5}$.

В 1930-х гг. ААамович продолжает следить за творчеством Зурова. В рецензии на публикации молодых прозаиков в альманахе «Круг» (1936) он называет Юрия Фемьзена, Василия Яновского, Сергея Шаршуна и Аеонида Зурова «цветом» парижской молодой бемлетристики, а их новые вещи считает не просто интересными, но и показательными. ЗАесь он впервые выделяет «обособленность» Зурова: «... “Новый ветер” Зурова кишний раз Аоказывает меАленный, верный, “крепкий” творческий рост автора. Это

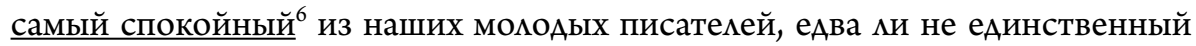
среАи них, каким-то чудом сохранивший во всех теперешних катастрофах, крушениях и передрягах некую “киассическую” уравновешенность тона и естественное, ничуть не наигранное стремление без следа раствориться в своих героях. Ава возможных преАположения: или он мало впечатлителен

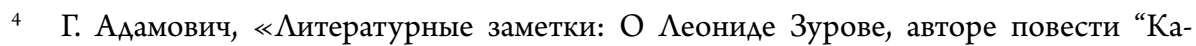
Ает” », Последние новости, 1929. 9 мая. № 2969. С. 3. Цит. по: Переписка И. А. и В. Н. Буниных с Г. В. ААамовичем (1926-1961) / Публ. О. Коростелева и Р. Аэвиса, в И. А. Бунин. Новые материалы. Вып. 1. М.: Русский путь, 2004. С. 15-16.

5 Вырезка со статьей Г. ААамовича «О Аеониде Зурове, авторе повести “Кадет”» с пометами И. Бунина, Русский архив АиАсского университета (Аалее РА $)$ ). MS. $1068 / 4974$.

6 ЗАесь и далее выделено мной - И. Б. 
и просто невнимателен к тому, что в наше время происходит с человеком и культурой, не слышит и не понимает взрывчатых, антицелостных мотивов эпохи, - или он очень силен и эпоху “преодолевает”. По ранним зуровским опытам первая гипотеза казалась мне вероятнее, но сейчас больше оснований отнестись к нему с Аоверием, - и остановиться на второй ${ }^{7}$.

Впрочем, отзывы ААамовича отражают его, прежде всего, Авойственное отношение к творчеству Зурова. Чего-то он в опубликованных вещах не угадывает - так, о публикации в журнале «Современные записки» зуровской «Молодости», представлявшей собой фрагменты трех глав романа «Поле», целиком изАанного позже, он пишет: «К сожалению только, читая “Молодость”, все время что-то вспоминаешь, отчетливее всего, пожалуй, Бориса Зайцева. Это зайцевский мир, зайцевский тон, к тому же и у самого Зайцева уже не вполне оригинальный, а им кишь очищенный и упорядоченный ${ }^{8}$. Хотя, на наш взгляА, зАесь уместнее было бы вспомнить не абстрактного Зайцева, но вполне конкретную перекличку с романом ВлаАимира Набокова «Аар», с тем же Авойным самоубийством Авоих влюбленных, в «Ааре» не состоявшимся из-за передумавшей умирать Аевушки, а у Зурова - с тщательно продуманным и довеАенным до конца.

На этот раз ААамович не заметих Аискретности повествования, хотя в слеАующей рецензии, отзываясь на публикацию Аругих глав того же романа в газете «Русские Записки», высказал это верное преАположение: «“Аозор”» Зурова - по-виАимому, глава из романа. Гцава сама по себе прекрасная, очень типичная Амя Зурова, спокойная в основном ощущении бытия, вопреки тем страхам и тревогам, о которых рассказывает. Странное Аело - творчество! Зуров пишет о бегстве помещиков из разоренного гнезда, о революиионных бедствиях и невзгодах, о России, охваченной темными предчувствиями, но в противоречие дословному содержанию текста, повесть измучает тепло и мир, даже, пожалуй, какой-то уют. Над всем, что Зуров рассказывает, как бы стоит незримый эпитет: ${ }^{9}$ «да зАравствует жизнь». <...> Зуров еАва ми не самый “почвенный” из наших молодых писателей, потому,

7 Г. ААамович, «Аитературные заметки: Альманах «Круг», книга I», ПослеАние новости, 1937. 25 ноября. № 6088. С. 3.

8 Г. ААамович, «“Современные записки”. Кн. 63. Часть митературная», Последние новости, 1937. 6 мая. № 5885. С. 3.

9 Против выделенного курсивом фрагмента Зуров отмечает на полях: «Смотри 1-ю рецензию Ю. Айхенвальда о книге “Кадет" - ААамович здесь повторяет его слова. А. 3. 1953 г.» (Ср.: «Миниатюра войны и мира, т. е. сражений, истязаний, расстремов - с одной стороны, и деревенского уюта, Волги, родины - с Аругой, эта частичная, в русской раме картина, уголок вечного мирового полотна в высокой мере УАалась молодому перу Аеонида Зурова. Ужасное изображает он, но так это перепиетено с трогательным и нежным, и грустным, что не мрак идет от его очерков на Аушу читателя, а какое-то тихое волнение, неАоумение, “светлая печаль”, кучи примирения» (Ю. АйхенвальА, «Аитературные заметки», Руль, 1928. 10 окт. № 2394. C. 3 . 
вероятно, и душевно стойкий, что у него крепче, чем у кого бы то ни было скрытая, не иАущая на убыль связь с родной землей. Он живет во Франции, как мог бы по прихоти судьбы жить на Антильских островах, - мало ки что в наши Ани случается! Но сознанием и Ааже вниманием он в России, и оттого выносливее своих сверстников, что никакие сквозные ветры на него ниоткуаа не Ауют ${ }^{10}$.

Постепенно в рецензиях Г. В. ААамовича складывается четко очерченная модель творчества Зурова: «спокойный», «почвенный» писатемь с «крепкой, как бы прирожАенной “памятью” о России ${ }^{11}$. Раньше многих Аругих ценителей особого русского языка зуровских рассказов (множество подобных писем он получит значительно позже, после изАания в 1958 году книги рассказов «Марьянка») ААамович отмечает: «"Ванюшины волосы”

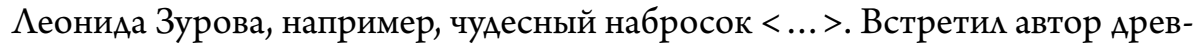
нюю старуху, помог ей добраться Ао Аому, вошел в избу, поговорил с нею и с ее сыном, тоже стариком. Аословное содержание "Ванюшиных волос" Ао крайности просто, Ааже убого. А рассказ всей сущностью своею ухоАит глубоко в землю, к матери-природе, и, ни о чем не споря, ни против чего не возражая, величаво оттеняет суетность нашего существования с его цивимизацией и прогрессом. В рассказе каждое слово пахнет Россией, и слишком мы зАесь стали к этому особому, таинственному запаху чувствительны, чтобы сразу его не умовить ${ }^{12}$.

ОтАельного упоминания заслуживает оценка ААамовичем Меонида Зурова как «душевно стойкого» писателя. ОАнако именно зАесь мнение критика не оправдалось, причем самым трагическим образом. Внимательный читатель мог заметить, что отношение ААамовича к Зурову переменилось, начиная со второй рецензии на книгу «КаАет». Само появление рецензии на книгу, вышедшую единожды четверть века назаА, явление необычное, к тому же рецензия как бы перечеркиваца уже упомянутое мнение ААамовича о Аебютной повести Зурова и отзыве на нее Бунина. На этот раз критик говорит об особой теме писателя, начавшейся с первой книги и проявившейся во всем его творчестве: «На провинцию <Рига> в русском китературном Париже посматривали с поощрительной снисхоАительностью, в сущности ничего оттуда не ожидая, - и, вероятно, так же была бы встречена и повесть Зурова, если бы не обратил на нее внимания Бунин. В оценках и сужАениях своих Бунин был строг, о произведениях молодого автора отзывался скупо и неохотно. У Зурова он без колебаний признал настоящий живой талант и сразу создал ему имя. < .. > Зуров - один из немногих, кто надежАы оправАам <..> не только настоящий писатемь, но и писатемь типично русский,

10 Вырезка со статьей Г. ААамовича «Русские записки <№ 2>» (ПослеАние новости, 1937. 16 дек. № 6109. С. 3) с пометами А. Зурова (РАА. МS. 1068/4974).

11 Г. ААамович, «Иитературные заметки (о Новоселье)», Русские новости, 1948, 23.04. C. 4.

12 Там же. 
которого естественно связать с былой нашей митературой и отвести ему в Аитературе новой отАемьное, заметное место ${ }^{13}$.

На первый взгля, рецензент описывает все ту же сконструированную им модель творчества Зурова, не находя ничего принципиально нового, все то же «вечное спокойствие природы», так же Зуров «только и Аышит свободно, оставаясь наедине с месами, озерами, степями ${ }^{14}$. Что же заставило критика совсем по-иному взглянуть на писатемя и коренным образом изменить свою, оАнажАы уже высказанную, оценку его книги?

ПреАысторией зАесь служит открывшаяся в 1953 году Аушевная болезнь Зурова, о которой ААамович писах В. Н. Буниной, отзываясь на ее сообщение и просьбу: «Очень рад был получить Ваше письмо, хотя и с печальными известиями. О болезни $\Lambda<$ еонида $>\Phi<$ еАоровича $>$ я знал. Знац и то, что он в кАинике. Есть ми наАежАа, что он поправится? Электрошоки - моАная сейчас вещь, но бывает, что организм их плохо выдерживает, и, по-моему, с ними надо быть очень осторожными. Я бы попробовац мечение во всяком случае безопасное - Christian Science ${ }^{15}$. Не знаю, верить ки в это или не верить. Я если и верю, то с оттенком «помоги моему неверию». Но я видел случаи - притом именно психические - когАа меАицина ничего не могла сАелать, а они что-то все-таки сАелали. Конечно, я с большой охотой напишу о $\Lambda<$ еониде $>$ $\Phi<$ еАоровиче> статью. Но будет это не раньше второй $1 / 2$ сентября, а я вернусь только к 10-12-му. Мне надо будет перечесть некоторые его повести и рассказы. <... Если это можно, передайте $\Lambda<$ ониду $>\Phi<$ еАоровичу> самые Аружеские привет и поклон ${ }^{16}$. Обещанную статью ААамович написах ${ }^{17}$.

Тем не менее, Зурова мечили электрошоком. Электрошоковая терапия используется и в наши Ани, но вот как описывает ее в книге об отце сын первого и еАинственного мауреата митературной премии знаменитой американской кинокомпании Метро ГолАвин Мейер, проходившего курс мечения всего за шесть мет до Зурова: «Пациент находится в полном сознании,

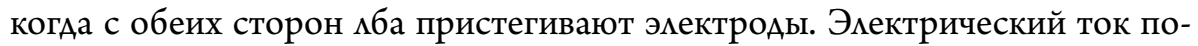
сылается в мозг $<\ldots>$, все тело сотрясают судороги. <...> Под спину клаАется клин, так что она выгибается. Виски намазывают какой-то Аурно пахнущей мазью. На голову прикрепляют какую-то упряжь. < ...> Ваши руки

13 Г. ААамович, «ИеониА Зуров», Новое русское слово, 1953. 29 ноября. № 15191. С. 8.

14 Там же.

15 Сторонники упоминаемой им доктрины Christian Science, преАложенной в 1879 году Мэри Бейкер ЭААи, всем методам мечения (медикаментозным, хирургическим и т. А.) преАпочитают исцеление через особые молитвы, направленные на пробужАение Ауховности в мышиении.

16 Письмо Г. В. ААамовича В. Н. Буниной от 23 авг. 1953 г., Переписка И. А. и В. Н. Буниных с Г. В. ААамовичем (1926-1961), в И. А. Бунин. Новые материалы. Вып I. М.: Русский путь, 2004. С. 109.

17 Г. ААамович, « АеониА Зуров», Новое русское слово, 1953. 29 нояб. № 15191. С. 8. 
связаны, ваши ноги держат. Вам в рот втыкают кляп и говорят: “Спасибо, милый”. Скоро все кончится. И вам будет хорошо ${ }^{18}$.

Что-то из всего этого ААамович явно знает, он Аогадывается о неизмечимости болезни Зурова и нисколько не верит в его исцеление: «Зурову буато бы мучше. Мне плохо верится, чтобы он мог поправиться совсем» ${ }^{19}$. Он оказался прав: у Зурова был серьезный рецидив в 1964 году. ОАнако страшных послеАствий этого мечения ААамович знать не мог.

Споры об электрошоковой терапии продолжаются до сих пор. Уже в 2000-х гг. американский психиатр Ажон ФриАберг утвержАах: «Я считаю, что потеря памяти от электрошоковой терапии (ЭШТ) это не “побочный эффект”, это главный эффект, и кучшие исследования обнаруживают ее у $100 \%$ субъектов». В русском языке нет множественного числа у слова «ложь», а в английском есть, и АЖ. ФриАберг нахоАит пять проявлений «большой

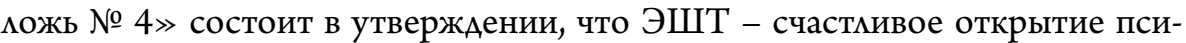
хиатрии. В Аействительности опубликованная Аоктором Саккеймом работа Аемонстрирует рецидивы болезни у 84\% пациентов в течение 6 месяцев после прекращения ЭШТ. А «Большая можь № 5» объявляет, что никто не знает механизма Аействия электрошока. Наоборот, возражает Аж. ФриАберг, все знают, как работает ЭШТ: «Она работает, стирая память и ужасая

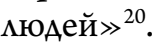

В случае с Зуровым этот вывоА полностью оправдывается: он работает, особенно после мечения, во второй половине 1950-х гг., неплодотворно, явно преодолевая некоторую заторможенность, бесконечно перерабатывая уже написанные эпизоды, главы, Ааже цемые произведения. В его библиографии 1950-е годы преАставлены крайне скупо. БАизко освеАомленный о трагедии Зурова, ААамович преисполнен эмпатии к настигнутому Аушевной болезнью товарищу по цеху. Теперь он, Аля карикатурного образа которого Набоков в «Ааре» выбрал в словаре Ааля первое значение слова «мортус» - «мертвый»), в своих откликах на творчество Зурова превращается в рецензента с «человеческим мицом», выполняющего функцию «мортуса» - «служителя при чумных», облегчающего болезнь (второе словарное значение слова).

Эта осознанно взятая Адамовичем на себя роль проясняется при сопоставлении его оценок творчества Зурова в печати и в Аичной переписке. В качестве примера приведем краткий обмен мнениями М. А. А^Аанова

18 L. Lockridge, Shade of the Raintree: The Life and Death of Ross Lockridge, Jr. NY: Penguin Books, 1994. С. 197-198 <перевоА мой. - И. Б.>.

19 Письмо Г. В. ААамовича И. В. Чиннову от 28 окт. 1953. Из писем Георгия ААамовича Игорю Чиннову/ Публ. М. Мимлер, Новый журнац, 1989. № 175. С. 247.

20 Testimony of John M. Friedberg, M. D., neurologist, before the mental Health Committee of the New York state assembly Martin Luster presiding, NYC, May 18, 2001. Retrieved from http://www.ect.org/?p=259 <перевоА мой. - И. Б.>. 
и Г. В. ААамовича о Авух маленьких рассказах Зурова, опубликованных в «Новом журнале» в 1955 году. Вопрос ААамовича, знающего о недружемюбном отношении А^данова к Зурову, воспринимается как отчасти провокационный: «По поводу “Нов<ого> журн<ала>" Вера Никомаевна мне пишет, что “все”, весь Париж, восхищены рассказами

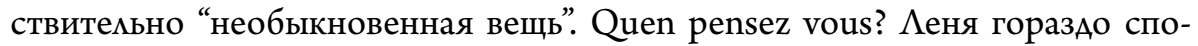
собнее, чем обычно о нем думают, и даже не так глуп, как иногда кажется. Но Аействительно ми это бессмертные шедевры? $\gg^{21}$.

Ответ А^Аанова свидетельствует, что он либо не в курсе состояния зАоровья Зурова, кибо не принимает его во внимание: «О Зурове с Вами согласен. Его Ава рассказа 22 недурно написаны, но оба крошечные. Второй все же слишком Алинен (страниц семь), чтобы быть стихотворением в прозе, - хотя по стилю это как будто так, Ааже слова, особенно глаголы, расставлены так, как их обычно в прозе не расставляют. (Сколько покойный Иван Алексеевич издевался над тем, что Зайцев ставит прилагательное после существительного!) Сюжета же нет ни в первом, ни во втором рассказе "Аени". Не знаю, очень ки восторгаются читатели, - мне никто, естественно, не говорил, да никто и не писал, - но, по-моему, в его интересах было Аля первого появления в "Новом журнале” Аать что-либо более значительное. А описания хороши. Вера Николаевна и мне написала о колоссальном успехе этих Авух рассказов! Я ей отвечу, что и мне они понравились, - в этом неискренности не будет ${ }^{23}$.

Обмен мнениями продолжается вопросом А^данова о В. Н. Буниной: «Говорила Аи она с Вами о "Аене” и его рассказах? Кстати, что же ВЫ о них Аумаете? Вы меня спрашивали ${ }^{24}$. В ответном письме Адамович высказывает свои претензии и к опубликованному в следующем номере «Нового журнала» рассказу Михаила Иванникова ${ }^{25}$, и к уже обсужАавшимся корреспондентами рассказам Зурова, причем ясно, что тот по-прежнему остается Аля критика «чужим» автором: «Читали ми Вы в “Н<овом> журнале” М. Иванникова (кто это?) - “Правила игры”. По-моему, очень талантливо, но до невозможности "воняет литературой” и похоже на Андрея Белого. А о Зурове - отвечаю на Ваш вопрос - я думаю, что его рассказики тоже

21 Письмо Г. В. ААамовича М. А. А^данову от 3 марта 1956, в «... Не скрывайте от меня Вашего настоящего мнения»: Переписка Г. В. ААамовича с М. А. А^Аановым (1944-1957). ПреАисл., подготовка текста и комментарии О. А. Коростелева. М.: Аом русского зарубежья имени Александра Сомженицына, 2011. С. 453.

22 В «Новом журнале» были опубликованы рассказы $\Lambda$. Ф. Зурова «Ксана» и «Гуси-лебеди» (Новый журнал, 1955. № 43. С. 20-32).

23 Письмо М. А. Алданова Г. В. Адамовичу от 10 марта 1956, в «... Не скрывайте от меня Вашего настоящего мнения»: Переписка Г. В. ААамовича с М. А. Алдановым (1944-1957). С. 454.

24 Письмо М. А. Алданова Г. В. ААамовичу от 10 мая 1956, там же. С. 462.

25 М. Иванников, «Правияа игры», Новый журнал, 1956. № 44. С. 5-21. 
талантливы и со всякими живописными Аостоинствами, но приторны в своей "русскости": наше русское небо, русские птицы - et ainsi de suite <и так Аамее>. Сами знаем, что русские, незачем напоминать. И наши птицы ничем не кучше Аругих ${ }^{26}$.

В 1958 году Зуров издает сборник рассказов «Марьянка», вызвавший множество одобрительных и благодарных откликов в виАе рецензий и писем автору. ААамович также выступает в качестве рецензента, причем, судя по статье, он «Марьянке» обрадовался: «ГАубокая, неподАельная ее "русскость” <...> это обрывки и осколки огромного исторического Аействия, всколыхнувшего Россию в наш век, и писатель с чудесной непосреАственностью Аает эту связь почувствовать ${ }^{27}$. Как виАим, критик хвалит писателя именно за то, о чем он не так Аавно с неприязнью писал Ацданову, - за «русскость .

Впрочем, нужно помнить, что новый отзыв, который иначе как восторженным не назовешь, свидетельствует не только и не столько о таланте Зурова, сколько, прежде всего, о сердечности ААамовича и его неуклонном следовании своей роли Мортуса. С присущим ему удивительным критическим охватом всего создаваемого в митературе на русском языке, он не мог не знать, что в сборник «Марьянка» вошии всего Ава относительно новых рассказа, те самые, о которых шиа речь в его переписке с Алдановым. Остальные были написаны значительно раньше - оАни более Аесяти мет назаА, а некоторые даже в начаме 1930-х гг.

ААамович отчетливо понимах Араматизм положения писателя, почти утратившего способность писать. Именно этим продиктована опубликованная похвала «Марьянке», в которой не нашлось места ни одному указанию на какие бы то ни было слабины автора. О недостатках говорилось только в письмах. В одном из них, А. А. Полякову, ААамович отзывается о той же «Марьянке» с похвалой, но все же и вполне критически: «Очень талантливо, но ужасно много слов, притом слишком красивых. Бунин прошелся бы по рукописи красным карандашом и половину вычеркнул бы ${ }^{28}$. Правота Г. В. ААамовича несомненна: в архиве Зурова сохранился экземпляр

26 Письмо Г. В. ААамовича М. А. Ацданову от 22 мая 1956, в «... Не скрывайте от меня Вашего настоящего мнения»: Переписка Г. В. ААамовича с М. А. Алдановым (1944-1957). С. 462.

27 Г. ААамович, «“Марьянка”. Рассказы Аеонида Зурова», Русская мысль, 1958. 11 авг. C. 8 .

28 Письмо Г. В. ААамовича А. А. Полякову от 4 сент. 1958; цит. по: О. Р. Аемидова, «Еще раз о маске: образ автора в письмах Георгия ААамовича», в Потаенная митература. Исследования и материалы. Вып. 2. Иваново, 2000. С. 156. 
повести «КаАет» с бунинской правкой ${ }^{29}$, основным направлением которой была редукция текста почти на треть ${ }^{30}$.

ТогАа же, в 1958-ом, и так же, в мичном письме, ААамович признается в том, что Зуров - не «его» автор: «... Читаю “Встречу” со смутными и глубокими (это не ко мне относится!) откликами. <..> А еще читаю Зурова: мне он совершенно не интересен, но я не могу не видеть, что это талантливый и настоящий писатемь. Вина, значит, во мне ${ }^{31}$.

Понимах $\Lambda$ и $\Lambda$. Ф. Зуров Авойственность оценок ААамовича? По-видимому, понимах, хотя еАва ми мог разобраться в ее причинах. Прочитав рецензию критика на «Марьянку», он пишет Микице Грин, с которой привык общаться без обиняков: «ААамович напечатал фельетон в "Н<овом>

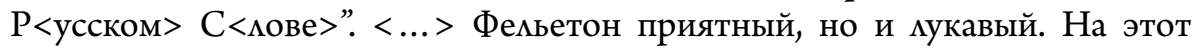
счет Г<еоргий $>\mathrm{B}<$ икторович> бомьшой мастер $>^{32}$.

ПослеАний подарок от Г. В. ААамовича Зуров получия за три с половиной месяца Ао своей внезапной смерти - в мае 1971 года он успел прочесть благодарный отзыв критика на новое, второе, изАание его Аавней повести «Отчина»: «... все так изменилось, что “Отчину” читаешь как нечто новое. $<\ldots>$ “Отчина" скорей похожа на протяжное песнопение, чем на повесть, и тема не столько повествовательна, сколько мирична ${ }^{33}$. Есть в этой статье, особенно в этом уАивленном «все так изменилось», та глубокая искренность, в которой уже никак не заподозрить ни снисхоАительности, ни Авойной оптики взгляАа, ни очереАного желания поААержать «чумного» только за то, что он «чумной». И это, на мой взгляА, быма мучшая из всех рецензий, написанных Г. В. ААамовичем на произведения Аеонида Зурова.

\section{Georgijs Adamovičs - mortus un vivus}

Georgijam Adamovičam bieži pārmeta kritisko vērtējumu subjektivitāti, atkarībā no tā, kā viņš dalīja autorus "savējos" vai "svešos”. Vladimirs Nabokovs viņu izvēlējās kā karikatūru varoṇa prototipu, literāro kritiķi Kristoforu Mortusu (latīnu 'mortuus' krieviskā adaptācija, proti, 'miris') romānā "Dāvana”. Rakstā parādīta cita, negaidīta G. Adamoviča personības puse - viņa dziḷā līdzjūtība prozaiķim Leonīdam Zurovam,

29 Cм.: A. J. Heywood. Catalogue of the I. A. Bunin, V. N. Bunina, L. F. Zurov and E. M. Lopatina Collections / ed. Richard D. Davies. Leeds: Leeds University Press, 2000. Кадет (1928 и б. А.) (отредактированные страницы книги, отчасти И. Буниным, Аля преАполагаемой публикации [вместе с «Отчиной»?] поА названием «Аве повести». РАА MS. 1068/274.

30 Более подробно см.: И. Белобровцева, «И. А. Бунин-реАактор: об окончательном (каноническом) тексте повести $\Lambda$. Ф. Зурова “Кадет” », Slavica Revalensia, № 1, 2014. C. 44-63.

31 Письмо Г. В. ААамовича С. Ю. Прегель от 17 июмя 1958, в Г. ААамович, ОАиночество и свобода. М.: Республика, 1996. Аоступно на https://e-libra.ru/read/445761izbrannye-pis-ma-raznyh-let.html.

32 Письмо А. Ф. Зурова М. Э. Грин от 21 нояб. 1958, РАА МS. 1068/2733/.

33 Г. ААамович, «“Отчина”, повесть Зурова», Новое русское слово, 1971. 23 мая. С. 8. 
kuru viņš vienmēr bija uzskatījis par "svešu”, estētiski svešu. Pēc tam, kad kḷuva zināms par Zurova psihisko slimību, G. Adamovičs uzṇēmās mortusa lomu, saskaņā ar Vladimira Dāla skaidrojošo vārdnīcu, tas ir 'kalpotājs, kas atvieglo vājprātā esošo, psihiski slimo cilvēku slimību'.

\section{Georgy Adamovich - Mortus and Vivus}

Georgy Adamovich, the outstanding literary critic of Russian emigration, was often rebuked for his extreme subjectivity, which was motivated by proximity, i. e. by whether the writers were considered close or "strangers". Vladimir Nabokov chose Adamovich as the character prototype for the literary critic Christopher Mortus (the adaptation of the Latin 'mortuus', namely 'dead') in the novel The Gift. The article reveals another, unexpected side of Adamovich's personality and his deep sympathy for the prose writer Leonid Zurov, whom he always considered aesthetically alien. After the news of Zurov's mental illness, Adamovich took on the role of a "mortus" who, according to Vladimir Dahl's Dictionary, is a servant relieving the sufferings of mentally ill people. 